\title{
Employer perspectives of the current and future value of STEM graduate skills and attributes: An Australian study
}

\author{
Gerry M. Rayner ${ }^{1}$ and Theo Papakonstantinou ${ }^{1}$ \\ gerry.rayner@monash.edu; theo.papakonstantinou@monash.edu \\ ${ }^{1}$ School of Biological Sciences, Monash University.
}

\begin{abstract}
Graduate employability has become increasingly contentious as employers call for greater development, evaluation and benchmarking of student skills and capabilities in university courses. However, the increasing range of graduate attributes and competencies demanded by industry is further pressuring an Australian higher education sector already stretched by greater student numbers and declines in government funding. Given these circumstances, there is a need to better understand employer perspectives of the current and future value of vocational, interpersonal and generic attributes of science, technology, engineering and mathematics (STEM) graduates. A survey of STEM graduate employers showed that vocational skills, such as graduates' abilities to contextually apply and develop knowledge, together with generic skills such as critical thinking and problem solving, were valued most highly. Conversely, self-confidence and independence, along with numeracy and related skills, were valued least by the employers. However, attributes such as flexibility/adaptability, self-confidence, personal planning and organisation and developing knowledge relevant to the position were all predicted to become significantly more valuable in a decade's time. The results of this study suggest that Australian undergraduate STEM curricula, which commonly focus on knowledge acquisition, be redesigned to provide students with opportunities to apply such knowledge more often, and in real life, industry-based contexts, such as workintegrated learning (WIL) and industry-based learning (IBL) programs. Through such initiatives, together with greater dialogue and collaboration between academics and employers, employability skills and attributes can be better inculcated in undergraduates, to the benefit of graduates and society as a whole.
\end{abstract}

Keywords: Graduate employability, employer perspectives, STEM education, graduate attributes, work-integrated learning

\section{Introduction}

Graduate employability has become an increasingly contentious issue (Hinchliffe, 2009; Ferns, 2012) as the tertiary education sector grapples with rapid change, and a range of other complex issues. These include the balancing of research and teaching, maintenance and assessment of academic standards amid competing pressures of reduced government funding and massification of undergraduate cohorts, and optimizing ICT for effective learning and teaching delivery (Christensen \& Eyring, 2012). As a consequence of the changes that are sweeping across the higher education landscape, the traditional model of a university degree - the inculcation of discipline-specific knowledge and associated relevant skills and attributes - has been called into question (Boud, 2013; Christensen \& Eyring, 2012). From a 
graduate's perspective, it is crucial that the changes occurring in higher education do not adversely impact the quality of their employability skills. In relation to this, graduate attributes can be categorised as vocational, interpersonal and generic. Vocational attributes are knowledge and practical-related abilities acquired in a specific discipline; generic attributes are transferable across different domains; interpersonal attributes are life skills used to work and interact effectively with others (Hernández-March, Martín del Peso, \& Leguey, 2009).

Over the past decade, employers have increasingly called for institutions to produce better skilled graduates (OECD, 2004; Tomlinson, 2008), with the wish list of desired graduate attributes seeming ever lengthier. Of generic skills, communication, critical thinking and problem solving appear to be most highly valued by employers (Clegg, 2013; Hodge, Nadler, Shore, \& Taylor, 2011; Prinsley \& Baranyi, 2015), as they enable graduates to resolve complex problems in real-life contexts, such as the $21^{\text {st }}$ century workplace (McLaughlin, Kennedy, \& Reid, 2015). Indeed, there may be connections among these attributes, as proficiency in writing is thought to enhance students' critical thinking skills (Quitadamo \& Kurtz, 2007). The transferability of such attributes from university to the workplace is also a crucial consideration, as it catalyses graduates' ability to maximize their job productivity (Jackson, 2014). However, while much has been learned about employer valuations of graduate skills and attributes (Jackson, 2014), there appears to be very little known about the value employers place on graduates' discipline knowledge: in particular, their application or further development of such knowledge in the workplace.

In regard to STEM education, while there have been increasingly vocal calls for graduates to be better prepared for the workforce, there still appears to be an emphasis on their acquisition of content knowledge (Wieman, 2007; Jones, 2014), at the expense of more work-relevant skills and capabilities applicable to real life settings. This is of particular significance to the considerable proportion of science graduates who enter non-science careers or professions (Rodrigues et al., 2007). The difficulty of finding the optimal balance between knowledge acquisition and skills development is likely due to several factors, including the rapidly increasing body of scientific knowledge, and a perceived requirement for its subsequent integration into associated curricula. Additionally, most university STEM educators are themselves scientists and engineers, and not necessarily skilled in pedagogy and course design that incorporates more work-related skills and capabilities. As a consequence, STEM undergraduates may be lacking opportunities to apply their content knowledge to contextually relevant situations.

Designing curricula to enhance graduate employability requires evidence-based approaches that will better inform stakeholders (universities, students and employers) about the most valued graduate skills and competencies (Whelan et al., 2010). Further, given the rapid rate of technological change, in addition to macro-industrial structures and regulatory oversight of graduate attributes, one cannot assume that current employer perspectives and valuations of graduate skills will remain the same a decade hence (Skills Australia, 2010). It is thus important to gauge employer perspectives of graduate skills priorities for the next decade, in order to provide potential signposts to enable fine-tuning of curricula and promotion of skills that will enhance graduates' work readiness. Given identified gaps in the literature around graduate employability, this study set out to better determine Australian STEM employer perspectives of the current and decadal value of a range of graduate attributes. At a broader level, this study sought to inform the debate around the structure of undergraduate STEM curricula, vis-à-vis optimisation of curricula including the incorporation of WIL, to enhance graduate work readiness and employability.

Rayner, G. \& Papakonstantinou, T. (2015). Employer perspectives of the current and future value of STEM graduate skills and attributes: An Australian study. Journal of Teaching and Learning for Graduate Employability, 6 (1), 100-115. 


\section{Methods}

\section{Employer survey structure}

This study assessed employer valuations of 13 graduate attributes, and their rankings of a subset of 10 attributes relative to one another. The rationale for this dual approach was that it enables comparison of attributes relative to each other. A survey methodology was adapted from Nair and Mertova (2009), incorporating both attribute valuations and rankings. This volunteer-response survey was emailed to 302 Australian STEM employers (predominantly Melbourne-based) of whom 128 (42.4\%) responded (Table 1). The survey, which took approximately 15 minutes to complete, asked employer representatives to rank each of the 13 attributes (Table 2) on a five point Likert scale from one (not important) to five (very important). No inducements or incentives were offered to potential respondents, all of whom had a direct role in hiring STEM graduates. The survey was administered under Human Research Ethics approval \# CF14/1703 - 2014000840.

Table 1: Industry Respondent Discipline Area (number in brackets indicates number of employers for each discipline subcategory; no number indicates 1 respondent)

\begin{tabular}{llll}
\hline Life sciences & $\begin{array}{l}\text { Biomedical and } \\
\text { biotechnology }\end{array}$ & $\begin{array}{l}\text { Physico-chemical } \\
\text { sciences }\end{array}$ & $\begin{array}{l}\text { Mathematics and } \\
\text { related }\end{array}$ \\
\hline \hline Biological research (18) & Medical research (15) & Analytical services (2) & Statistical services (2) \\
\hline \hline Heritage consultancy (2) & $\begin{array}{l}\text { Pharmaceutical } \\
\text { sciences (3) }\end{array}$ & Chemical R \& D (8) & Transport research (2) \\
\hline Water research (6) & Biotechnology (9) & $\begin{array}{l}\text { Chemical } \\
\text { manufacturing (7) }\end{array}$ & Engineering consulting (5) \\
\hline $\begin{array}{l}\text { Science communication } \\
(2)\end{array}$ & Medical equipment (3) & Climate science (2) & Defence / government (4) \\
Other (6) & Scientific sales (5) & Other (11) & Engineering R\&D (5) \\
& Veterinary Pathology & Geosciences & Engineering consulting (3) \\
\hline \hline
\end{tabular}

Skills and attributes were grouped as vocational (discipline-specific knowledge or skills), generic (characteristic of all disciplines) or interpersonal (relevant to the individual). A subset of 10 skills and attributes was selected for employer ranking, determined on a scale of one to 10 , with 10 being the highest and one the lowest ranking (Table 3). No thematic coding of solicited comments was carried out, but specific comments were included where relevant. Further perspectives were sought from respondents about the value of different degrees (e.g. BSc, Masters, PhD) and the quality of Monash University science programs and graduates.

Rayner, G. \& Papakonstantinou, T. (2015). Employer perspectives of the current and future value of STEM graduate skills and attributes: An Australian study. Journal of Teaching and Learning for Graduate Employability, 6 (1), 100-115. 
Table 2: Graduate Attribute Groupings, together with Definitions, Example Skills and References to Relevant Literature (V: Vocational; G: Generic; I: Interpersonal)

\begin{tabular}{|c|c|c|c|}
\hline Skill / attribute & Definition & Examples & References \\
\hline $\begin{array}{l}\text { Discipline } \\
\text { knowledge (V) }\end{array}$ & $\begin{array}{l}\text { A set of understandings } \\
\text { which is more than broad } \\
\text { knowledge of a scientific field }\end{array}$ & All STEM fields & 1 \\
\hline $\begin{array}{l}\text { Apply discipline } \\
\text { knowledge }(V)\end{array}$ & $\begin{array}{l}\text { Use learned information and } \\
\text { understandings in various } \\
\text { situations }\end{array}$ & $\begin{array}{l}\text { Graduate matching to an } \\
\text { occupation inside the scientific } \\
\text { domain }\end{array}$ & $2,3,4$ \\
\hline $\begin{array}{l}\text { Develop discipline } \\
\text { knowledge }(V)\end{array}$ & $\begin{array}{l}\text { Acquire information and } \\
\text { understanding in a scientific } \\
\text { field }\end{array}$ & $\begin{array}{l}\text { Graduates need to be able to use } \\
\text { new and emerging technologies }\end{array}$ & 5,6 \\
\hline Problem solving (G) & $\begin{array}{l}\text { Find solutions to difficult or } \\
\text { complex issues }\end{array}$ & $\begin{array}{l}\text { The Top } 25 \text { project; the } \\
\text { Chemistry Collaboration project }\end{array}$ & $7,8,9$ \\
\hline Critical thinking (G) & $\begin{array}{l}\text { Objectively analyse and } \\
\text { evaluate an issue in order to } \\
\text { form a judgment }\end{array}$ & $\begin{array}{l}\text { The Top } 25 \text { project; STEM-based } \\
\text { literature review }\end{array}$ & $7,8,9$ \\
\hline $\begin{array}{l}\text { Written } \\
\text { communication (G) }\end{array}$ & $\begin{array}{l}\text { Communicate by means of } \\
\text { written symbols (either } \\
\text { printed or handwritten) }\end{array}$ & $\begin{array}{l}\text { The Top } 25 \text { project; STEM-based } \\
\text { literature review }\end{array}$ & $7,8,9$ \\
\hline $\begin{array}{l}\text { Oral } \\
\text { communication (G) }\end{array}$ & $\begin{array}{l}\text { Express information or ideas } \\
\text { orally }\end{array}$ & $\begin{array}{l}\text { The Top } 25 \text { project; STEM-based } \\
\text { plenary lectures }\end{array}$ & $7,8,9$ \\
\hline $\begin{array}{l}\text { Numeracy and } \\
\text { quantitative } \quad \text { skills } \\
(G)\end{array}$ & $\begin{array}{l}\text { Understand and work with } \\
\text { numbers and related } \\
\text { mathematical concepts }\end{array}$ & $\begin{array}{l}\text { Correctly determine volumes, } \\
\text { correlations, ratios, } \\
\text { concentrations etc. }\end{array}$ & 10,11 \\
\hline $\begin{array}{l}\text { Personal planning, } \\
\text { organisation (I) }\end{array}$ & $\begin{array}{l}\text { Accurately estimate the time } \\
\text { and effort required to } \\
\text { complete one or more tasks }\end{array}$ & $\begin{array}{l}\text { Graduate need to be able to use } \\
\text { new and emerging technologies }\end{array}$ & 6 \\
\hline Teamwork (I) & $\begin{array}{l}\text { The combined action or } \\
\text { actions of a group of people }\end{array}$ & $\begin{array}{l}\text { The Top } 25 \text { project; veterinary } \\
\text { science collaborative project }\end{array}$ & $\begin{array}{l}12 \\
14\end{array}$ \\
\hline Ethics (I) & $\begin{array}{l}\text { Moral principles } \\
\text { person's orning a } \\
\text { behaviour }\end{array}$ & $\begin{array}{l}\text { Piltdown Man hoax; veterinary } \\
\text { science collaborative project }\end{array}$ & $\begin{array}{l}12 \\
14\end{array}$ \\
\hline $\begin{array}{l}\text { Flexibility } \\
\text { adaptability (I) }\end{array}$ & $\begin{array}{l}\text { Able to cope with changed } \\
\text { circumstances, and to adapt } \\
\text { to fit changed circumstances }\end{array}$ & $\begin{array}{l}\text { Graduates need to be able to use } \\
\text { new and emerging technologies }\end{array}$ & 6 \\
\hline $\begin{array}{l}\text { Self-confidence and } \\
\text { independence (I) }\end{array}$ & $\begin{array}{l}\text { Confidence in self or abilities, } \\
\text { freedom from aid, influence } \\
\text { control, support of others }\end{array}$ & $\begin{array}{l}\text { Independently undertake a WIL } \\
\text { placement }\end{array}$ & 15 \\
\hline \multicolumn{4}{|c|}{$\begin{array}{l}\text { 1: Hernández-March, Martín del Peso, \& Leguey (2009); 2: Jones (2009); 3: Nagarajan \& Edwards (2014); 4: } \\
\text { Rae (2007); 5: Heijke, Meng, \& Ris (2003); 6: Coll \& Zegwaard (2006); 7: Clegg (2013); 8: Hodge et al. (2011); ): } \\
\text { Prinsley \& Baranyi (2015); 10: Black, Yasukawa, \& Brown (2013); 11: Saunders \& Zuzel (2010); 12: Business } \\
\text { Council of Australia (2011); 13: Casner-Lotto \& Barrington (2006); 14: Schull, Morton, Coleman, \& Mills (2012); } \\
\text { 15: Rampersad \& Patel (2014) }\end{array}$} \\
\hline
\end{tabular}

\section{Statistical analysis}

Means and standard error measurements (SEMs) of data from employer surveys were calculated using a standard Likert-type scale from 1 to 5 (for each attribute), with subset

Rayner, G. \& Papakonstantinou, T. (2015). Employer perspectives of the current and future value of STEM graduate skills and attributes: An Australian study. Journal of Teaching and Learning for Graduate Employability, 6 (1), 100-115. 
rankings from 1 to 10 . One-tailed $t$-tests were applied to derived means, with differences considered significant if $p<0.05$.

\section{Research findings}

\section{Graduate attribute analysis}

\section{Vocational graduate attributes}

A very high proportion of employers agreed or strongly agreed (Likert-scale score of 4 or 5 ) that currently, important vocational graduate attributes include: (i) discipline knowledge in a major field of study (84\% agreed or strongly agreed that this was valuable); (ii) an ability to apply knowledge relevant to the discipline (91\%); and (iii) an ability to develop knowledge relevant to the position (94\%). An ability to apply knowledge relevant to the discipline, and an ability to develop knowledge relevant to the position, were valued significantly higher than discipline knowledge in a field of study ( $t=2.1, p<0.0001 ; t=2.9, p<0.0001$ respectively) (Figure 1).

In regard to the future (decadal) valuation of vocational attributes, and contrasting with current employer perceptions, employers valued the ability to develop knowledge relevant to the position significantly higher than both discipline knowledge $(t=3.9, p<0.0001)$ and the ability to apply knowledge relevant to the discipline $(t=1.4, p=0.002)$ (Figure 1$)$. The ability to apply knowledge was similarly valued higher than discipline knowledge $(t=2.4, p<$ 0.0001). There was a significant increase in employers' valuation, in a decade's time, of graduates' ability to develop knowledge relevant to the position $(t=1.2, p=0.007)$. This is reflected in the higher proportion of employers who agreed or strongly agreed that this was a valuable attribute (current - 94\%, decadal - 98\%).

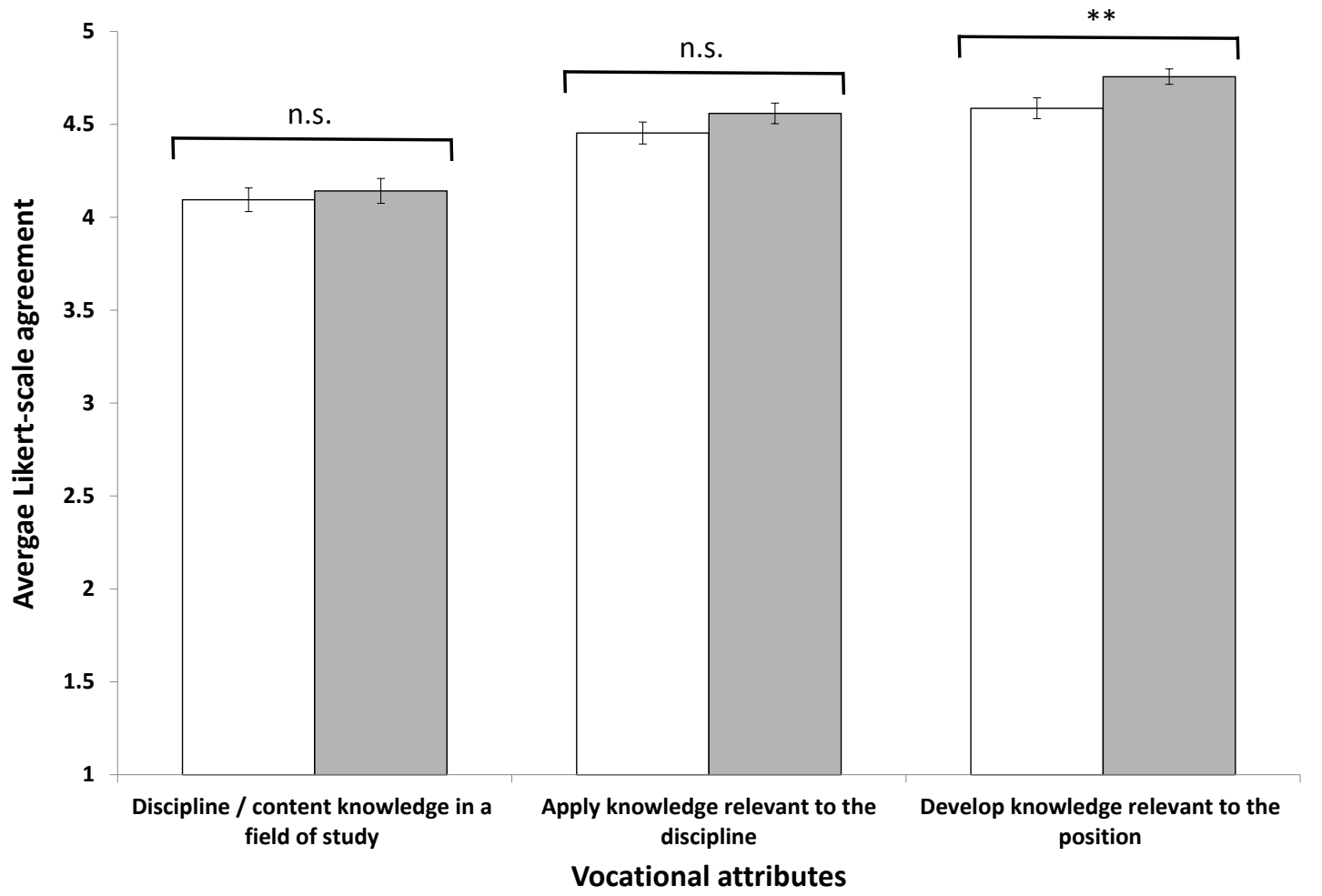

Figure 1: Current and Decadal Employer Valuations (means +/- SEM) of Vocational Attributes. (Open and shaded columns represent current and decadal employer valuations respectively $(n=128)$. n.s. denotes not significant, ** denotes $p<0.01)$

Rayner, G. \& Papakonstantinou, T. (2015). Employer perspectives of the current and future value of STEM graduate skills and attributes: An Australian study. Journal of Teaching and Learning for Graduate Employability, 6 (1), 100-115. 


\section{Generic graduate attributes}

Generic graduate attributes which are currently highly valued by the surveyed employers were: (i) problem solving abilities (98\% agreed or strongly agreed they were valuable); (ii) critical thinking skills (95\%); (iii) written communication skills (91\%); and (iv) oral communication skills (90\%). By contrast, numeracy and related skills were the least valued generic attributes (71\%). Future (decadal) valuations of these attributes were, overall, approximately the same $(98 \%, 97 \%, 93 \%, 92 \%$, and $79 \%$ respectively).

Currently, problem solving and critical thinking skills are valued significantly higher than oral communication skills ( $t=1.6, p=0.001 ; t=1.4, p=0.003$ respectively), and numeracy and related skills ( $t=3.2, p<0.0001 ; t=3.1, p<0.0001$ respectively) (Figure 2$)$. In addition, written communication skills were more highly valued than numeracy and related skills $(t=$ 1.8, $p=0.0002)$. With regard to employer perceptions of the future value of generic attributes, there was no significant increase or decrease from current-day valuations for any of the five attributes in question (Figure 2). However, the current pattern of valuation of these attributes remains unchanged in a decade's time: numeracy and related skills remain the lowest valued of the generic attributes (Figure 2).

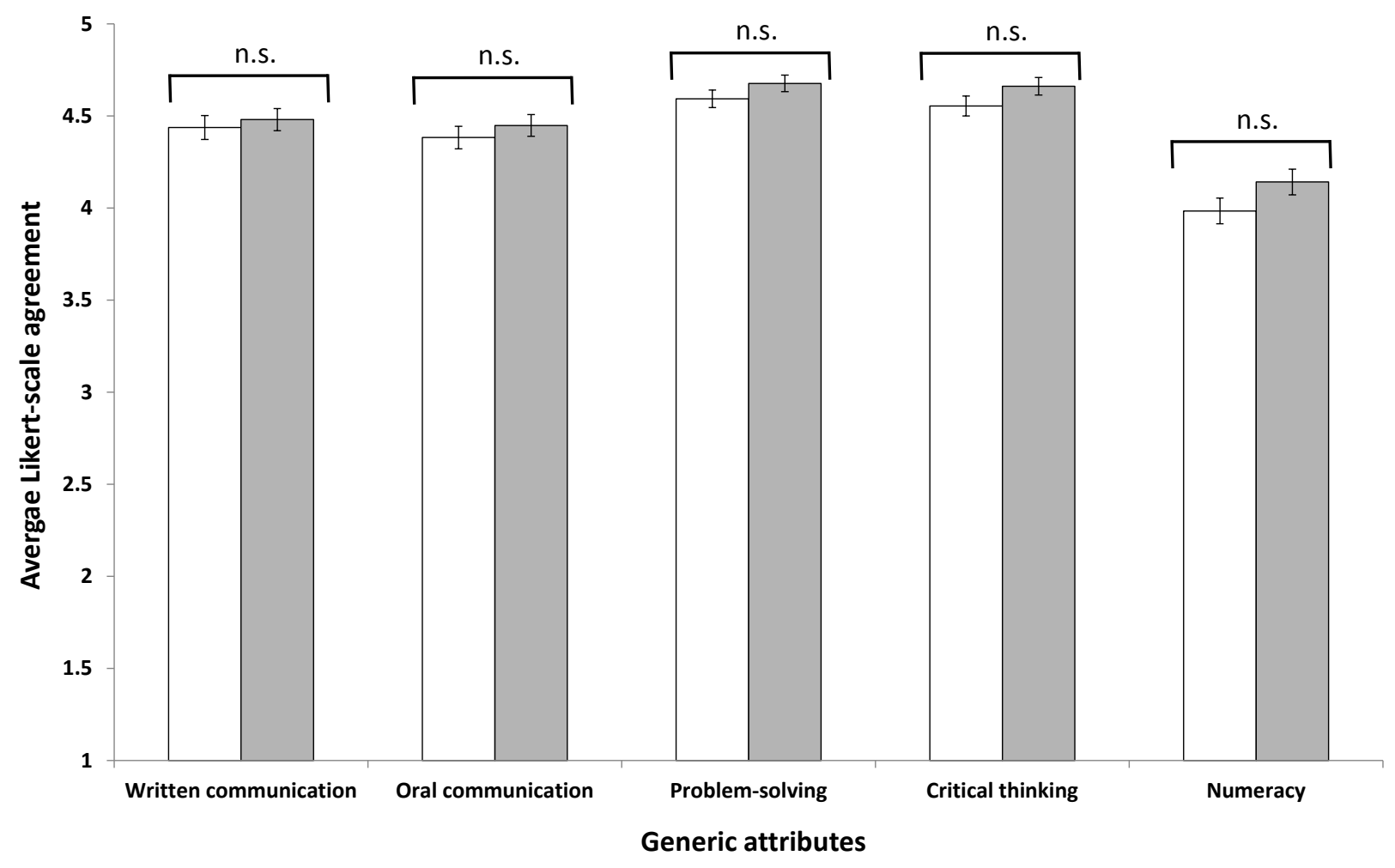

Figure 2: Current and Decadal Employer Valuations (means +/- SEM) of Generic Attributes. (All other indications are as for Figure 1.) 


\section{Interpersonal graduate attributes}

Interpersonal graduate attributes that were highly valued by employers were: (i) personal planning and organisational skills ( $92 \%$ of surveyed employers agreed or strongly agreed that this was valuable); (ii) an ability to work effectively in teams (91\%); (iii) an understanding of ethical conduct (85\%); and (iv) a capacity for flexibility or adaptability (85\%). Selfconfidence and independence, however, were valued lowest (76\%) of this set of attributes.

Employers valued the ability to work effectively in teams more highly than a capacity for flexibility / adaptability $(t=1.5, p=0.002)$, personal planning and organisational skills $(t=$ $1.4, p=0.003)$, and self-confidence and independence $(t=3.1, p<0.0001)$ (Figure 3$)$. Selfconfidence and independence was valued significantly lower than all other interpersonal attributes, both currently and in a decade hence (Figure 3). Employers predicted that flexibility / adaptability would be more valuable in ten years' time compared to the present ( $t$ $=1.8, p=0.0003)$, along with self-confidence $(t=0.9, p=0.04)$ and personal planning and organisational skills $(t=1.0, p=0.02)$. This finding is consistent with the higher proportion of STEM employers who agreed or strongly agreed that these three attributes will become more valuable, when comparing decadal and current percentages (97\% versus $85 \%$, 83\% versus $76 \%$, and $96 \%$ versus $92 \%$ respectively).

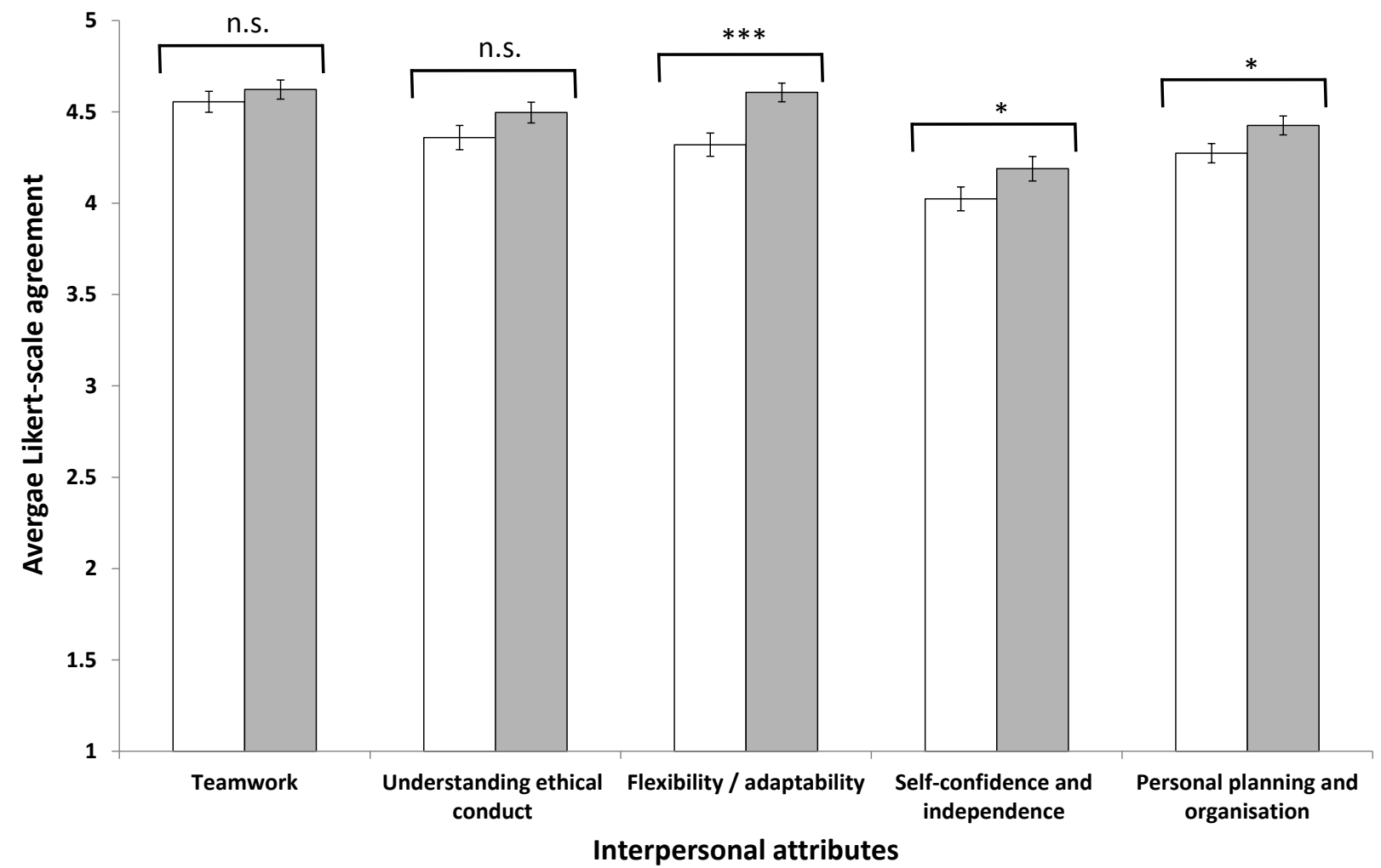

Figure 3: Current and Decadal Employer Valuations (means +/- SEM) of Interpersonal Attributes. ( ${ }^{*}$ denotes $p<0.05$, ${ }^{* *}$ denotes $p<0.001$, with other indications as per Figure 1) 


\section{Employer ranking of graduate skills and attributes}

Of the ten skills and attributes, an ability to (i) apply knowledge relevant to the discipline and (ii) develop knowledge relevant to the position were ranked highest by employers (Table 2). These two attributes also received the highest number of top ('10') rankings by employers. The third lowest and lowest ranked skills and attributes were (i) the ability to work in teams and (ii) numeracy and related skills, respectively, which also received the lowest number of '10' rankings (Table 3). While graduates' ability to problem-solve, discipline knowledge and understanding of ethical conduct received the equal third highest number of '10' rankings, these three attributes had significantly different mean rankings (Table 3 ). This suggests a bimodal pattern of employer responses regarding an understanding of ethical conduct, the lowest ranked of the three. Critical thinking, communication skills, and a capacity for flexibility / adaptability were intermediate in employer rankings, and flexibility / adaptability received the fourth highest percentage of '10' rankings (Table 3).

Table 3: Mean ( \pm SEM) Employer Ranking (10 = highest, 1 = lowest) of Selected Graduate Skills and Attributes, and Percentage of Employers' Highest Rank for Each Skill / Attribute $(n=118)$ ( $V=$ Vocational, $G=$ Generic, and I = Interpersonal skill I attribute)

\begin{tabular}{lcc}
\hline Skill I attribute & Ranking & \% Employers '10' ranking \\
\hline \hline Ability to apply relevant knowledge (V) & $6.6 \pm 0.3$ & 21.2 \\
Ability to develop relevant knowledge (V) & $6.5 \pm 0.2$ & 13.6 \\
Problem solving (G) & $6.1 \pm 0.2$ & 12.4 \\
Critical thinking (G) & $5.8 \pm 0.2$ & 11.0 \\
Communication (G) & $5.8 \pm 0.2$ & 7.6 \\
Discipline knowledge (V) & $5.4 \pm 0.3$ & 12.7 \\
Capacity for flexibility / adaptability (I) & $5.2 \pm 0.3$ & 5.9 \\
Ability to work in teams (I) & $5.0 \pm 0.2$ & 4.2 \\
Understanding of ethical conduct (I) & $4.5 \pm 0.3$ & 11.9 \\
Numeracy and related (G) & $4.1 \pm 0.3$ & 3.4 \\
\hline \hline
\end{tabular}

\section{Employer comments on graduate skills and attributes}

When asked about which attributes are best inculcated in STEM graduates, some relevant employer comments were that:

Problem solving, the ability to think critically and adaptability are key attributes that graduates need. (Employer A)

The best graduates are well rounded individuals with impressive scores as well as early vocational experience, they may have travelled, have broad interests and language skills. These attributes demonstrate a maturity and independence that employers will value. (Employer B) 
Overall, graduates who are well prepared for employment have been given the opportunity to apply their knowledge, skills and abilities to realistic scenarios in a practical setting. They have also gained experience working in teams. (Employer C)

In response to a question about what was lacking in STEM graduates, five employers noted that:

Most graduates are unable to spot flaws in their own deliverables. Practice in critical evaluation of their own or others' work from a client's perspective (especially management) would be beneficial. (Employer D)

Most graduates I talk to have little to no training in efficient and proper writing skills and most graduates I employ require 'retraining'. (Employer E)

Overall, graduates could improve their non-technical skills and attributes such as communication, interpersonal skills and self-awareness. (Employer C)

The interpersonal skills - working in teams and understanding how that impacts performance. Being work ready, understanding roles, OH\&S and working for a manager - how to get the best outcome for all. (Employer F)

As with all graduates some basic teamwork skills can be lacking. (Employer G).

Interestingly, despite employers' low valuation and ranking for independence and selfconfidence, two of them made positive comments on these attributes. They wrote:

A skill which young graduates (from any university) often need to develop is being able to work independently and with minimal direction. Even post-graduate students often get through their degrees by doing exactly what their supervisor tells them to do. This is not conducive to being able to independently solve problems once they get into the work force. (Employer $\mathrm{H}$ )

I feel that the biggest barrier with those students who have not been previously exposed to a commercial workplace, is an apparent lack of confidence. i.e. they deserve to be confident as the work they undertake is well within their capability; however just the manner they present may unfortunately be taken as a lack of self-confidence by some employees. (Employer I)

\section{Discussion and implications}

Over the past decade, graduate employability has become an issue of increasing importance for higher education providers (Rae, 2007; Ferns, 2012; Rampersad \& Patel, 2014). Rather than designing courses that are highly valued by academics, we found that there is an urgent need for Australian universities to liaise and communicate much more effectively with industry and employer groups. These discussions will provide greater clarity about the 'state of play' regarding the skills and attributes that will be most valued a decade from now. Additionally, universities should have more valid means to authentically assess student work readiness as they progress toward graduation (Oliver, 2015). Finally, regardless of the degree of alignment between universities and employers, graduate capabilities must reflect the current and future priorities of the work place in order to enhance graduates workreadiness. 


\section{Vocational attributes}

Employers' high valuation of vocational-related skills is not surprising given that they are greatly sought-after graduate attributes (Heijke, Meng, \& Ris, 2003), and reflect graduates' levels of knowledge and their ability to apply it. While this finding may reinforce a contention that the primary role of universities is to educate (Boulton \& Lucas, 2011) and for employers to train, there is a need for institutions to provide students with an ability for metacognition to know what they know and do not know (Hargrove, 2013) - and suitable training for later employment (Lam, 2007). This outcome is relevant to broader issues such as curriculum development and pedagogical approaches (Jones, 2013), particularly in regard to the connection between these components and the enhancement of vocational skills.

Employers' valuation of graduates' ability to apply knowledge relevant to a discipline, and to develop knowledge relevant to the workplace, over purely discipline knowledge itself, is consistent with other findings (Jones, 2009; Nagarajan \& Edwards, 2014; Rae, 2007). However, it is counter to the broader view that graduate attributes are largely generic and transcend disciplinary contexts (Assiter, 1995; Barrie, 2006; Drummond, Nixon, \& Wiltshire, 1998). Employer prioritisation of graduates' contextual application and development of knowledge and skills may relate to their capacity for higher order thinking, such as the analysis, synthesis, and integration of workplace-related information (Krathwohl, 2002). Greater proficiency in higher order thinking thus provides the context for 'doing a job' more successfully.

In regard to rankings, the high value placed on graduates' ability to apply knowledge to workplace environments is unsurprising, given its contextual relevance to the actual work being done by the graduate and the likely correlation between such skills and workplace productivity. That employers have ranked this attribute very highly for a long time (Celuch \& Slama, 1999; Stewart \& Knowles, 2000) is indicative of its ongoing importance, despite broader trends in STEM curricula to an emphasis on knowledge acquisition. Further, an ability to apply knowledge in different contexts is linked with higher order thinking skills such as critical thinking (Dwyer, Hogan, \& Stewart, 2014), a connection that reinforces long-held calls for greater inculcation of such skills in undergraduate curricula (Ennis, 1987).

The optimal vehicle for better inculcation of vocationally-related attributes in Australian university STEM curricula is through targeted capstone units or WIL programs (Papakonstantinou, Charlton-Robb, reina, \& Rayner, 2013), and/or increased effectiveness of existing WIL programs (Rayner \& Papakonstantinou, 2015) such that the learning tasks students do better resemble those that they will later undertake in the workplace (Oliver, 2015). These requirements are likely to assume greater urgency given the rapidly changing nature of the workplace, and increased complexity that will accompany such change (Skills Australia, 2010). This urgency is echoed by the increased employer valuation of the future worth of graduates' ability to develop knowledge relevant to the workplace, a decade from now.

\section{Generic attributes}

The high value employers placed on graduates' problem solving and critical thinking skills aligns with Hodge et al. (2011), and may not be unexpected, as these attributes are also associated with higher order thinking (Crebert, Bates, Bell, Patrick, \& Cragnolini, 2004). In spite of this, problem solving and critical thinking are considered to be underrepresented in undergraduate science degrees (Hager, Sleet, Logan, \& Harper, 2003; Kim et al., 2013). If correct, the genuine inculcation of these skills in students may require redevelopment of STEM curricula and associated practical activities, perhaps using identified threshold learning outcomes (Jones \& Yates, 2010; Jones, Yates, \& Kelder, 2012) as templates for such.

Rayner, G. \& Papakonstantinou, T. (2015). Employer perspectives of the current and future value of STEM graduate skills and 
Employers' low valuation and concomitant low ranking of graduates' numeracy and related quantitative skills (QS) is surprising, given calls by the Australian Academy of Science (2006) for graduates to be better equipped with such skills. However, our findings are consistent with what has been previously reported (Black, Yasukawa, \& Brown, 2013; Saunders \& Zuzel, 2010). As an illustration of this low priority, an academic intervention programme designed to enhance the employability of unemployed graduates focused on improving their general self-efficacy, rather than their numeracy and related skills (Hazenberg, Seddon, \& Denny, 2014). The contrast between our findings and the high value science academics place on QS may illustrate the differing priorities of academia and employers, given that such academics need to possess strong proficiency in statistics and related QS to successfully research and publish in their discipline. Such disconnects between the worlds of employers and academia have long been noted (Dunne, Bennett, \& Carré, 1997), and may be difficult to resolve.

\section{Interpersonal attributes}

Employers' low valuation of graduates' self-confidence and independence does not align with its previously reported high regard by industry, and supposed association with attributes such as initiative, creativity, and an ability to 'get the job done' (Rampersad \& Patel, 2014). While our findings conflict with what has been previously reported, the importance of graduate self-confidence may be industry-specific, or alternatively it could be that our results indicate a recent shift in employer attitudes towards this attribute. Employers' low ranking of an ability to work in teams and an understanding of ethical conduct is surprising, especially given the corresponding high levels of agreement that these skills and attributes are important, and the broad recognition of teamwork as a desirable graduate attribute (Business Council of Australia, 2011; Casner-Lotto \& Barrington, 2006; Schull et al., 2012). The discordance between our results and those observed elsewhere provides a potential opportunity for further investigation.

Employer predictions of the greater value of graduates' flexibility / adaptability skills in ten years' time is consistent with previous findings (Coll \& Zegwaard, 2006), which reflects the rapidly changing nature of the workplace; particularly in the spheres of science and technology. It may also, to some extent, reflect employers' own uncertainty about the nature of their future workplace, which was reflected in the intermediate employer ranking for this attribute. While calls for graduates to be more adaptable or flexible have been made for specific industries, such as oil refining (Horne, 2008) and engineering (Spinks, Silburn, \& Birchall, 2006), this appears to be a poorly defined capability and requires considerable further research, particularly for science graduates.

\section{Conclusions}

Employers' high valuation and ranking of vocationally-related skills, namely the development and application of knowledge in workplace contexts, unsurprisingly reflects their priorities and interests in terms of workplace productivity. Conversely, the relatively mediocre rankings of generic skills, in particular numeracy and related skills is unexpected, given the considerable push for inculcation of such skills across all educational sectors. Attributes such as flexibility and adaptability are unsurprisingly predicted to be of considerably greater value in the future, due to the rapidly changing nature of workplaces, driven largely by technology but also by broader economic factors. This study shows that while there is a need for considerably greater dialogue between industry and the tertiary education sector, this should not be demand-driven. This is because STEM graduate employers still appear to highly value the pedagogical elements that universities do best: namely, the inculcation of relevant discipline knowledge and higher order thinking skills for the next generation of STEM graduates. We believe that integration of authentic WIL tasks into STEM curricula will not threaten these elements of an undergraduate education, but rather enrich them.

Rayner, G. \& Papakonstantinou, T. (2015). Employer perspectives of the current and future value of STEM graduate skills and attributes: An Australian study. Journal of Teaching and Learning for Graduate Employability, 6 (1), 100-115. 


\section{Acknowledgments}

The authors would like to thank all the STEM organisations and their employees who took part in this survey study and who provided valuable and insightful feedback. The authors would also like to thank two anonymous reviewers for their very helpful comments and suggestions. 


\section{References}

Assiter, A. (Ed.) (1995). Transferable skills in higher education. London: Kogan Page.

Australian Academy of Science. (2006). Mathematics and statistics: Critical skills for Australia's future, The National Strategic Review of Mathematical Sciences Research in Australia. Accessed 20/7/2013. http://www.review.ms.unimelb.edu.au/FullReport2006.pdf

Barrie, S.C. (2006). Understanding what we mean by the generic attributes of graduates. Higher Education, 51(2), 215-241.

Black, S., Yasukawa, K., \& Brown, T. (2013). The literacy and numeracy 'crisis' in Australian workplaces: Discursive rhetoric vs. production floor realities. Journal of Education and Work DOI: 10.1080/13639080.2013.854875.

Boud, D. (Ed.) (2013). Enhancing learning through self-assessment. New York: Routledge.

Boulton, G., \& Lucas, C. 2011. What are universities for? Chinese Science Bulletin, 56(23), 2506-2517.

Business Council of Australia. (2011). Lifting the quality of teaching and learning in higher education. Melbourne, Australia: Business Council of Australia.

Casner-Lotto, J., \& Barrington, L. (2006). Are they really ready to work? Employers' perspectives on the basic knowledge and applied skills of new entrants to the 21st century US workforce. Partnership for 21st Century Skills, 1-64. Accessed 19/10/2014. http://files.eric.ed.gov/fulltext/ED519465.pdf

Celuch, K., \& Slama, M. (1999). Teaching critical thinking skills for the twenty-first century: An advertising principles case study. Journal of Education for Business, 74(3), 134-139.

Christensen, C.M., \& Eyring, H.J. (2012). The innovative university: Changing the DNA of higher education from the inside out. Forum for the Future of Higher Education, 47-53. Accessed 29/7/2014. https://net.educause.edu/ir/library/pdf/ff1207s.pdf

Clegg, J.K. (2013). Careers: 5 keys to fruitful collaborations. Chemistry in Australia Feb 2013: 34-35.

Coll, R.K., \& Zegwaard, K.E. (2006). Perceptions of desirable graduate competencies for science and technology new graduates. Research in Science \& Technological Education, 24(1), 29-58.

Crebert, G., Bates, M., Bell, B., Patrick, C.J., \& Cragnolini, V. (2004). Developing generic skills at university, during work placement and in employment: Graduates' perceptions. Higher Education Research \& Development, 23(2), 147-165.

Drummond, I., Nixon, I., \& Wiltshire, J. (1998). Personal transferable skills in higher education:The problems of implementing good practice. Quality Assurance in Education, 6(1), 19-27.

Dunne, E., Bennett, N., \& Carré, C. (1997). Higher education: Core skills in a learning society. Journal of Education Policy, 12(6), 511-525.

Dwyer, C.P., Hogan, M.J., \& Stewart, I. (2014). An integrated critical thinking framework for the 21st century. Thinking Skills and Creativity, 12, 43-52.

Ennis, R.H. (1987). Critical thinking and the curriculum. In M. Heiman \& J. Slomianko (Eds.), Thinking skills instruction: Concepts and techniques (pp. 40-48). Washington: National Education Association.

Ferns, S. (2012). Graduate employability: Teaching staff, employer and graduate 
perceptions. Paper presented at the 2012 Australian Collaborative Education Network National Conference, 'Collaborative Education: Investing in the Future'. Accessed 1/10/2014. http://acen.edu.au/2012conference/wpcontent/uploads/2012/11/84 Graduate-employability.pdf

Hager, P., Sleet, R., Logan, P., \& Hooper, M. (2003). Teaching critical thinking in undergraduate science courses. Science \& Education, 12(3), 303-313.

Hargrove, R.A. (2013). Assessing the long-term impact of a metacognitive approach to creative skill development. International Journal of Technology and Design Education, 23(3), 489-517.

Hazenberg, R., Seddon, F., \& Denny, S. (2014). Programme recruitment and evaluation: The effect of an employability enhancement programme on the general self-efficacy levels of unemployed graduates. Journal of Education and Work DOI: 10.1080/13639080.2014.900165.

Heijke, H., Meng, C., \& Ris, C. (2003). Fitting to the job: The role of generic and vocational competencies in adjustment and performance. Labour Economics 10 (2), 215-229.

Hernández-March, J., Martín del Peso, M., \& Leguey, S. (2009). Graduates' skills and higher education: The employers' perspective. Tertiary Education and Management 15 (1), 116.

Hinchliffe, G. (2009). Employer concepts of graduate employability. Accessed 15/7/2014. http://dera.ioe.ac.uk/13064/1/6572.pdf

Hodge, D.C., Nadler, M.K., Shore, C., \& Taylor, B.A. (2011). Institutionalizing large scale curricular change: The top 25 project at Miami University. Change: The Magazine of Higher Learning, 43(5), 28-35.

Horne, R.N. (2008). The future of petroleum-and of petroleum education. Stanford University. Accessed 5/11/2014. http://energyseminar.stanford.edu/sites/all/files/eventpdf/CUP2008.pdf

Jackson, D. (2014). Modelling graduate skill transfer from university to the workplace. Journal of Education and Work DOI: 10.1080/13639080.2014.907486

Jones, A. (2009). Redisciplining generic attributes: The disciplinary context in focus. Studies in Higher Education, 34(1), 85-100.

Jones, A. (2013). There is nothing generic about graduate attributes: Unpacking the scope of context. Journal of Further and Higher Education, 37(5), 591-605.

Jones, S.M. (2014). Assessing the science knowledge of university students: Perils, pitfalls and possibilities. Journal of Learning Design, 7(2), 16-27.

Jones, S.M., \& Yates, B.F. (2010). Threshold Learning Outcomes for science graduates: A progress report on the Learning and Teaching Academic Standards project. Paper presented at the Proceedings of the 16th UniServe Science Annual Conference, Sydney, September. Accessed 16/4/2013. http://ojsprod.library.usyd.edu.au/index.php/IISME/article/view/4650

Jones, S.M., Yates, B.F., \& Kelder, J-A. (2012). Learning and teaching academic standards for science: Where are we now? Paper presented at Proceedings of The Australian Conference on Science and Mathematics Education, Sydney, September. Accessed 16/4/2013. http://ojs-prod. library.usyd.edu.au/index.php/IISME/article/view/5904

Kim, K., Sharma, P., Land, S.M. , \& Furlong, K.P. (2013). Effects of active learning on enhancing student critical thinking in an undergraduate general science course. Innovative Higher Education 38 (3), 223-235. 
Krathwohl, D.R. (2002). A revision of Bloom's taxonomy: An overview. Theory into practice, 41(4), 212-218.

Lam, A. (2007). Knowledge networks and careers: Academic scientists in industry-university links. Journal of Management Studies, 44(6), 993-1016.

McLaughlin, P., Kennedy, B., \& Reid, J. (2015). Learning for life and work in a complex world. Paper presented at Proceedings of $38^{\text {th }}$ HERDSA conference, Melbourne, July. Accessed 29/10/2015.http://www.herdsa.org.au/wpcontent/uploads/conference/2015/HERDSA 2015 McLaughlin.pdf

Nagarajan, S., \& Edwards, J. (2014). Is the graduate attributes approach sufficient to develop work ready graduates? Journal of Teaching and Learning for Graduate Employability, 5(1), 12-28.

Nair, C.S., \& Mertova, P. (2009). Conducting a graduate employer survey: A Monash University experience. Quality Assurance in Education, 17(2), 191-203.

Oliver, B. (2015). Redefining graduate employability and work-integrated learning: Proposals for effective higher education in disrupted economies. Journal of Teaching and Learning for Graduate Employability, 6(1), 56-65.

Organisation for Economic Co-operation and Development (OECD). (2004). Career guidance and public policy: Bridging the gap. Accessed 4/1/2014. http://www.oecd.org/dataoecd/33/45/34050171.pdf

Papakonstantinou, T., Charlton-Robb, K., Reina, R.D., \& Rayner, G. (2013). Providing research-focussed work-integrated learning for high achieving science undergraduates. Asia-Pacific Journal of Cooperative Education, 14(2), 59-73.

Prinsley, R., \& Baranyai, K. (2015) Stem skills in the workforce: What do employers want? Occasional Paper Series, Issue 9, Office of the Chief Scientist, Australian Government, Canberra.

Quitadamo, I.J., \& Kurtz, M.J. (2007). Learning to improve: Using writing to increase critical thinking performance in general education biology. CBE Life Sciences Education, 6(2), 140-154.

Rae, D. (2007). Connecting enterprise and graduate employability: Challenges to the higher education culture and curriculum? Education + Training, 49(8/9), 605-619.

Rayner, G., \& Papakonstantinou, T. (2015). Student perceptions of their workplace preparedness: Making work-integrated learning more effective. Asia-Pacific Journal of Cooperative Education, 16(1), 13-24.

Rampersad, G., \& Patel, F. (2014). Creativity as a desirable graduate attribute: Implications for curriculum design and employability. Asia-Pacific Journal of Cooperative Education, 15(1), 1-11.

Rodrigues, S., Tytler, R., Darby, L., Hubber, P., Symington, D., \& Edwards, J. (2007). The usefulness of a science degree: The 'lost voices' of science trained professionals. International Journal of Science Education, 29(11), 1411-1433.

Saunders, V., \& Zuzel, K. (2010). Evaluating employability skills: Employer and student perceptions. Bioscience Education, 15, 1-15.

Schull, D.N., Morton, J.M., Coleman, G.T., \& Mills, P.C. (2012). Final-year student and employer views of essential personal, interpersonal and professional attributes for new veterinary science graduates. Australian Veterinary Journal, 90(3), 100-104.

Rayner, G. \& Papakonstantinou, T. (2015). Employer perspectives of the current and future value of STEM graduate skills and attributes: An Australian study. Journal of Teaching and Learning for Graduate Employability, 6 (1), 100-115. 
Skills Australia (2010). Australian Workforce Futures: A National Workforce Development Strategy. Canberra: Commonwealth of Australia. Accessed 2/10/2014. http://www.awpa.gov.au/our-work/Workforce\%20development/national-workforcedevelopment-strategy/documents/WWF strategy.pdf

Spinks, N., Silburn, N., \& Birchall, D. (2006). Educating engineers for the 21st Century: The industry view. Accessed 5/11/2014.

http://www.ersilia.org/documents/Crisis vocacions/Henley\%20Report\%20\%20Educating\%20Engineers\%20for\%20the\%2021st\%20Century.pdf

Stewart, J., \& Knowles, V. (2000). Graduate recruitment and selection: Implications for HE graduates and small business recruiters. Career Development International, 5(2), 6580.

Tomlinson, M. (2008). 'The degree is not enough': Students' perceptions of the role of higher education credentials for graduate work and employability. British Journal of Sociology of Education 29(1), 49-61.

Whelan, B., Oliver, B., Hunt, L., Hammer, S., Jones, S., \& Pearce, A. (2010). Capturing stakeholder perceptions of graduate capability development: Challenges associated with graduate employability indicators. In Proceedings of the Australian Collaborative Education Network National Conference (ACEN 2010). (pp. 498-506). Australian Collaborative Education Network.

Wieman, C. (2007). Why not try a scientific approach to science education? Change: The Magazine of Higher Learning, 39(5), 9-15. 